\title{
Efektivitas Self-Talk Terhadap Pengelolaan Kesehatan Mental di Tengah Pandemi COVID-19
}

\author{
Risky Maulana Hidayatullah ${ }^{1}$ \\ Faizatun Nisa Al Aluf 2 \\ 1,2,Fakultas Ilmu Sosial dan Humaniora, Universitas Ibrahimy Situbondo \\ E-mail: rizkimaula7@gmail.com
}

\begin{abstract}
This study aims to test the effectiveness of self-talk to overcome psychological disorders in the covid 19 pandemic. The hypothesis of this research is that there is an effect of self-talk to overcome psychological disorders in the covid 19 pandemic. This research method is a quasi-experimental type of one group pre-test and post-test design. The number of subjects are 20 subjects who experienced psychological disorders. The research instrument to screen for psychological disorders uses the Self Reporting Questionnaire (SRQ). Data analysis uses $t$ test to test psychological disorders before and after the intervention. The results of the $t$-test analysis showes the $t$-value $=6.159$ while the $p$-value is $0.000(p<0.05)$, it means that there is a significant influence between pre-test and post-test data on research subjects, it means that there is a positive effect of self-talk in overcoming psychological disorders.
\end{abstract}

Keywords: COVID-19 Pandemic, Mental Health, Self-talk

\begin{abstract}
Abstrak
Penelitian ini bertujuan menguji efektivitas Self talk untuk mengatasi gangguan psikologi ditengah pandemic covid 19. Hipotesis penelitian ini terdapat pengaruh Self talk untuk mengatasi gangguan psikologi ditengah pandemic covid 19. Metode penelitian ini kuasi eksperimen jenis one group Pre-test dan post-test design. Jumlah subjek 20 subjek yang mengalami gangguan psikologi. Alat ukur penelitian untuk mengskrining gangguan psikologi menggunakan Self Reporting Questionnaire (SRQ). Analisis data menggunakan Uji $t$ untuk menguji gangguan psikologi sebelum dan sesudah pemberian intervensi. Hasil analisis uji $t$ menunjukkan nilai $t=6.159$ sedangkan nilai $p 0.000$ $(p<0.05)$ hal tersebut mengartikan terdapat pengaruh yang signifikan antara data pre test dan post test pada subjek penelitian hal tersebut mengartikan terdapat pengaruh yang positif pemberian Self talk dalam mengatasi gangguan psikologi.
\end{abstract}

Kata Kunci: Kesehatan Mental, Pandemi COVID-19, Self-talk

Copyright (C) 2021 Rizki Maulana Hidayatullah, Faizatun Nisa Al Aluf 


\section{Pendahuluan}

Coronavirus disease 2019 yang disebut sebagai COVID-19 adalah penyebab pandemi di banyak negara. Banyak dampak negatif akibat wabah ini yang menyerang kesehatan fisik maupun psikologis pada individu secara umum (Banerjee, 2020). Menurut Brooks dkk. (2020), dampak psikologis akibat pandemi ini diantaranya gangguan stres pascatrauma (post-traumatic stress disorder), ketakutan akan tertular virus, kegelisahan, kebingungan, insomnia, frustrasi dan merasa tidak berdaya. Hampir semua jenis gangguan psikologi baik yang ringan hingga berat terjadi dimasa pandemi.

Kebiasaan baru adalah sesuatu yang dapat dibentuk, adaptasi terhadap situasi baru memang tidak semudah yang dibayangkan,namun meskipun demikian bukan berarti kita tidak bisa melakukannya. Membentuk kebiasaan baru walaupun sulit akan tetapi jika dilakukan secara sungguh-sungguh dan konsisten maka sedikit demi sedikit akan terbentuk. Individu sering sekali merasa permasalahan yang dihadapi oleh dirinya sendiri tidak bisa tertangani sehingga menjadi pesimis, cemas, bingung, tidak mampu mengungkapkan, sampai pada masanya tidak mampu untuk bertindak lagi. Ketidakmampuan dalam coping stress dalam menghadapi konflik dapat membuat menumpuknya segala permasalahan yang belum terselesaikan. Permasalahan yang dihadapi seseorang yang tidak terselesaikan dengan baik dapat mengarah pada gangguan psikologi seperti paranoid, depresi, delusi, halusinas, gangguan emosional.

Kondisi psikologis yang tidak sehat dapat mempengaruhi semua aspek seseorang baik kognitif, perilaku, sampai keadaan fisiologisnya. Permasalahan yang pernah dialami dimasa lalu, dan kejadian-kejadian yang tidak mengenakkan lainnya dalam hidup harus diselesaikan terlebih dahulu sebelum menghadapi permasalah lainnya. Permasalahan yang terjadi pada seseorang terkadang bertentangan dengan ketidak percayaan diri hingga berujung menyalahkan diri sendiri, semakin kuat menolak maka seseorang akan semakin sulit untuk menerima atau berdamai dengan diri sendiri.

Para ahli telah bersepakat bahwa kesehatan mental dan kesehatan fisik adalah suatu hal yang saling berkaitan dan harus dikelola secara seimbang. Keseimbangan antara kesehatan mental dan kesehatan fisik di masa pandemi covid-19 juga telah menjadi salah satu perhatian bagi pemerintah. Kementerian Kesehatan telah menerbitkan sebuah buku pedoman tentang Dukungan Kesehatan Jiwa Dan Psikososial (DKJPS) pada pandemi covid-19. Berdasarkan pada kebijakan Badan Kesehatan Dunia (WHO), buku ini adalah salah satu tindakan dalam memberikan dukungan kesehatan jiwa dan psikososial bagi seluruh warga khususnya yang berkaitan langsung dalam pandemic covid-19 seperti tenaga kesehatan maupun pasien yang menderita covid-19, (Kementerian Kesehatan RI, 2019).

Berbagai macam dampak dari pandemi covid-19 yang terjadi dinilai menjadi stressor baru bagi masyarakat (Fiorillo \& Gorwood, 2020). Stigma dan diskriminasi masyarakat dalam menghadapi covid-19 seperti mengindar bahkan tidak mengijinkan masuk saat tenaga kesehatan mengunjungi rumah, dikucilkan saat terpapar virus covid19, adanya larangan menggunakan fasilitas umum seperti taman, tempat ibadah dan lainnya (Fiorillo dan Gorwood, 2020; Ridlo, 2020; Talevi, dkk., 2020). 
Berdasarkan data yang diperoleh Perhimpunan Dokter Spesialis Kedokteran Jiwa Indonesia (PDSKJI) yang meneliti tentang perkembangan psikologis masyarakat saat pandemi COVID-19 menunjukkan bahwa 64,3 \% dari 1.522 responden mengalami masalah gangguan psikologis sebagai dampak dari adanya pandemi ini. Responden tersebut terdiri dari perempuan sebanyak 76,1 \% yang berusia dari 14 tahun-71 tahun. Mereka berasal dari beberapa wilayah yaitu Jawa Barat $(23,4 \%)$, Jawa Tengah $(15,5$ \%), Jawa Timur (12,8\%), dan DKI Jakarta (16,9\%).

Kasus lain terjadi pada seorang pemuda dari kota Tangerang berusia 20 tahun yang diduga mengakhiri hidupnya karena permasalahan pekerjaan akibat pandemi covid-19 (Fiorillo \& Gorwood, 2020). Konflik yang dihadapi seseorang mengakibatkan gangguan stress, depresi, sampai mengarah pada gangguan psikosomatis dan gangguan mental lainnya seharusnya dapat ditangani baik oleh dirinya sendiri maupun bantuan para ahli. Di Indonesia permasalahan kesehatan mental merupakan hal yang cukup serius dikarnakan kondisi alam yang berubah, kompetisi antar manusia, sampai kurangnya dukungan dari lingkungan sosial. Gangguan kesehatan mental di Indonesia setiap tahunnya mengalami peningkatan yang cukup signifikan ditambah terjadinya pandemi Covid-19. Menurut Riskesdas (2018) jumlah kasus gangguan kesehatan mental dan emosional sebanyak 9,8 \% dari 300.000 rumah tangga yang berusia 15 tahun keatas. Banyak faktor yang mengakibatkan tingginya kasus tersebut seperti kurangnya pemahaman masyarakat dalam menjaga kesehatan mental, banyak yang menganggap bahwa gangguan kejiwaan berkaitan dengan hal mistis, hingga banyaknya individu yang merasa lebih takut jika orang lain mengetahui dirinya mengalami gangguan kejiwaan sehingga enggan untuk memeriksakannya ke para ahli.

Pandemi ini mengharuskan masyarakat untuk lebih banyak tinggal di dalam rumah, bahkan pekerjaan, sekolah, hingga hiburan rekreasional semua harus dikerjakan di rumah karena untuk menghindari kerumunan yang dapat memicu tertularnya covid19. Berada di rumah mungkin mampu menghindari diri dari virus namun disisi lain perubahan kondisi dari sebelumnya sering berinteraksi dengan orang lain kini dipaksa untuk menghindarinya, hal tersebut memicu kebosanan hingga berakibat munculnya kecemasan, stres, depresi dan masalah lainnya di tambah berita dengan keadaan mencekam semakin banyaknya korban berjatuhan akibat terpapar covid-19. Kondisi pandemi yang menimbulkan banyak masalah mengakibatkan pentingnya masyarakat mendapatkan pelayanan kesehatan mental. Namun kenyataannya dikarnakan menghindari pelayanan yang bersifat tatap muka maka banyak layanan psikologi yang ditutup sementara atau hanya melayani via daring saja.

Kebutuhan menjaga kesehatan mental sangat dibutuhkan oleh semua kalangan. Meskipun sulitnya mendapatkan pelayanan kesehatan dimasa pendemi ini bukan berarti hal ini menjadi penghalang untuk menerapkan pemeliharaan kesehatan mental secara mandiri. Kunci utama menjaga kesehatan mental dengan baik terdapat dalam diri sendiri (Self), karena kesehatan mental yang baik berawal dari dari diri kita sendiri, seberapa besar besar permasalahan yang dihadapi seseorang jika memilili self yang kuat maka apapun masalahnya dapat dihadapi dengan psikologis yang sehat. Salah satu cara untuk menjaga kesehatan mental yang baik dengan teknik self healing. Self healing 
mempunyai banyak manfaat untuk menjaga Kesehatan mental dimasa pandemic, selain penerapannya bisa dilakukan secara mandiri tanpa perlu melibatkan orang lain juga dapat dilakukan pengulangan secara konsistensi untuk mendapatkan hasil yang lebih maksimal dalam mempertahankan kesehatan mental atau untuk mengobati gangguan psikologi.

Self healing adalah metode pengobatan yang bukan dengan menggunakan obat medis maupun cara tradisional, melainkan merubah pengolahan pikiran negative menjadi positif dengan mengeluarkan perasaan dan emosi negative yang terpendam di dalam diri seseorang. Self healing merupakan latihan praktis yang dapat dikerjakan secara mandiri sekitar 15-20 menit dan sebaiknya dalam sehari dilakukan setidaknya 2 kali (Redhodkk, 2019).

Perbaikan pada diri bertujuan untuk mengeluarkan ekspresif yang tertunda, emosi yang bersifat negative, bahkan trauma masa lalu yang sudah disimpan sejak lama dan sangat menganggu pikiran seseorang. Setiap orang memiliki kemampuan yang berbeda-beda untuk menerapkan self healing dan hal tersebut bergantung dengan kecocokan model self healing yang dilakukan. Salah satu jenis self healing yang sering digunakan untuk mengelola kesehatan mental di tengah pandemi adalah dengan positive self talk. Menurut Burnett (1996) Self talk merupakan pembicaraan yang bersifat internal dan terstruktur serta berasal dari diri sendiri untuk diri sendiri sebagai gambaran pemikiran mengenai dirinya dan dunia (dalam Marhani, dll, 2018). Secara terperinci konsep dari Self talk adalah pembicaraan terstruktur didalam diri yang membahas mengenai diri sendiri dan keadaan disekitarnya. Bedasarkan konsep tersebut dapat dikatakan bahwa positive Self talk mengarah pada pembicaraan positif yang berasal dari diri sendiri mengenai kehidupan yang terjadi pada dirinya dan kehidupan didunia.

Positive Self talk dapat membantu seseorang dalam memotivasi kinerjanya. Menurut Chroni (dalam Indraharsani \& Budisetyani, 2017) mengungkapkan bahwa Self talk adalah sebuah dialog ekesternal ataupun internal yang dilakukan untuk memberikan instruksi dan penguatan pada kinerja seseorang dalam menghadapi permasalahn. Dalam proses melakukan teknik Self talk seseorang melakukan dialog antara dirinya sendiri kepada dirinya sendiri secara internal dan bertujuan membantu untuk dalam meningkatkan motivasi.

Kedua pengertian di atas menjelaskan bahwa konsep positive Self talk adalah dialog yang dilakukan seseorang secara eksternal maupun internal terkait kehidupannya secara positif dan dapat meningkatkan motivasi serta kesehatan mental menjadi lebih lebih baik.

Penjelasan sebelumnya dapat dipahami bahwa positive self talk dapat membantu seseorang untuk meningkatkan kinerja dengan dialog positif pada diri sendiri terkait hal yang berhubungan dengan dunia dan diri sendiri. Penelitian yang dilakukan oleh Wulaningsih (2016) menyebutkan terdapat beberapa manfaat dari positive Self talk adalah:

a) Positive Self talk mampu memperbaiki suasana hati karena dialog positif yang dilakukan mampu menuntun alam bawah sadar seseorang sehingga dialog positif 
yang diucapkannya menjadi bentuk nyata dari perilaku seseorang.

b) Mengarahkan diri dan merangsang untuk mengevaluasi tindakan yang telah dilakukan adalah salah satu dari manfaat positive self talk. Hal ini terjadi karena apabila hal-hal positif diungkapkan maka akan memunculkan tindakan pada hal-hal yang positif dalam mencapai tujuan seperti memberikan motivasi, menambah percaya diri, memperjelas tujuan, meningkatkan semangat dan menjadikan seseorang tidak mudah putus asa.

c) Positive Self talk membantu untuk mengubah suasana hati yang menjadi lebih baik saat individu menghadapi masalah dengan mengungkapkan perkataan positif dalam pikiran.

Gantika, Eka, \& Karsih (2011) telah merancang beretapa tahapan dalam melakukan teknik positive Self talk, rancangan tersebut adalah sebagai berikut:

a) Klien diarahkan untuk memperlihatkan mengenai pemikiran yang tidak logis. Hal ini dapat membantu klien untuk memahami bagaimana klien dapat memunculkan pikiran irasional. Tahapan ini bertujuan agar klien dapat memunculkan pemikiran bahwa mereka memiliki potensi untuk mengubah dirinya menjadi lebih baik.

b) Tahap kedua mengarahkan klien untuk menghadapi diri dalam mengubah pikiran irasionalnya. Hal ini dilakukan bersama klien dengan mengeksplorasi ide dan tujuan yang rasional.

c) Pemikiran rasional klien akan terus diperkuat dengan kalimat motivasi yang bersifat positif.

Tahapan demi tahapan tersebut dilakukan dengan sedikit demi sedikit pengarahan pemikiran irasional menuju pikiran yang rasional dengan bantuan dialog positif pada diri terkait hal-hal yang bersangkutan dengan lingkungan sekitar dan diri sendiri.

\section{Metode}

Penelitian yang dilakukan menggunakan desain Pre experimental dengan jenis one group Pre-test dan post-test design. Mengacu pada pendapat Sugiyono (2015) pada desain one group pretest-posttest yaitu ditahap awal melakukan pengukuran untuk mengukur kesehatan mental subjek penelitian (pretest), selanjutnya memberikan perlakuan (treatment) berupa positive Self talk dan setelah itu dilakukan pengukuran kesehatan mental subjek lagi (posttest). Hasil kedua pengukuran pre-test dan post-test dibandingkan untuk menguji apakah treatment yang diberikan dapat mengelola kesehatan mental di tengah pandemi covid-19. Subjek dalam penelitian ini sejumlah 20 orang yang mengalami gangguan psikologi.

Terdapat dua variabel yang dikaji dalam penelitian ini, yaitu penerapan teknik positive Self talk sebagai variabel bebas (X) atau independent variable dan kesehatan mental sebagai variabel terikat (Y) atau dependent variable.

Teknik pengumpulan data penelitian ini menggunakan alat ukur self-reporting questionnaire (SRQ) adalah koesioner yang dikembangkan oleh WHO dan di diadopsi Sri Idaiani (2009) yang berfungsi sebagai skrining dasar gangguan psikologi dan 
digunakan untuk keperluan penelitian yang telah dilakukan di berbagai Negara. Administrasi alat ukur SRQ-20 cukuplah sederhana dari total 20 soal yang disajikan responden diminta memilih jawaban "ya" atau "tidak". Berdasarkan Riskesdas (2007) dari 20 soal SRQ-20 selanjutnya dilakukan sistem cut off point dengan nilai batas pisah 6. Cut off point tersebut mengartikan jika responden menjawab 6 atau lebih jawaban "ya" dari 20 pertanyaan yang diajukan maka responden tersebut diindikasi mengalami gangguan mental emosional.

\section{Hasil dan Pembahasan}

Hasil Penelitian ini bertujuan untuk mengetahui efektivitas dari terapi Self talk terhadap 20 subjek yang terindikasi gangguan psikologi melalui koesioner SRQ-20. Dari hasil pre-test 20 subjek tersebut sejumlah 4 orang adalah laki-laki dan 16 orang adalah perempuan. Selain itu dari 20 subjek terdapat 11 orang berusia antara 15-19 tahun yang sekolah SMA sederajad dan 9 orang berusia antara 20-30 tahun yang berprofesi sebagai mahasiswa dan bekerja.

\begin{tabular}{|c|c|c|c|c|}
\hline \multicolumn{5}{|c|}{ Tabel 01. Pre Test Gangguan Psikologi } \\
\hline Skoring & $\begin{array}{c}\text { Jumlah } \\
\text { Subjek }\end{array}$ & Percent & Kategori & Keterangan \\
\hline 6 & 5 & $25 \%$ & $\geq 6$ & Abnormal \\
7 & 4 & $20 \%$ & $\geq 6$ & Abnormal \\
8 & 6 & $30 \%$ & $\geq 6$ & Abnormal \\
9 & 2 & $10 \%$ & $\geq 6$ & Abnormal \\
10 & 1 & $5 \%$ & $\geq 6$ & Abnormal \\
11 & 1 & $5 \%$ & $\geq 6$ & Abnormal \\
15 & 1 & $5 \%$ & $\geq 6$ & Abnormal \\
Total & 20 & $100 \%$ & & \\
\hline
\end{tabular}

Hasil Pre test yang dilakukan terlihat rata-rata subjek berada pada skor antara 6, 7, dan 8. Terdapat pula subjek dengan skor tertinggi yaitu skor 15 sejumlah 1 sabjek serta keseluruhan subjek menurut hasil koesioner SRQ-20 keseluruhannya berada pada kategori $\geq 6$ atau Abnormal. Setelah melakukan intervensi atau perlakuan eksperimen berupa terapi Self talk kepada 20 subjek yang mengalami indikasi gangguan psikologi akhirnya mendapatkan hasil post test sebagaimana table berikut ini :

Tabel 02. Pos Test Gangguan Psikologi

\begin{tabular}{|c|c|c|c|c|}
\hline Skoring & $\begin{array}{c}\text { Jumlah } \\
\text { Subjek }\end{array}$ & Percent & Kategori & Keterangan \\
\hline 0 & 1 & $5 \%$ & $<6$ & Normal \\
1 & 5 & $25 \%$ & $<6$ & Normal \\
2 & 6 & $30 \%$ & $<6$ & Normal \\
3 & 2 & $10 \%$ & $<6$ & Normal \\
4 & 2 & $10 \%$ & $<6$ & Normal \\
5 & 1 & $5 \%$ & $<6$ & Normal \\
6 & 2 & $10 \%$ & $\geq 6$ & Abnormal \\
7 & 1 & $5 \%$ & $\geq 6$ & Abnormal \\
Total & 20 & $100 \%$ & & \\
\hline
\end{tabular}


Hasil dari pos test yang lakukan setelah memberikan perlakuan berupa terapi Self talk kepada 20 subjek yang mengalami indikasi gangguan psikologi terdapat 17 subjek atau $85 \%$ berada pada kategori $<6$ atau Normal, sedangkan 3 subjek atau 15\% tetap berada pada kategori $\geq 6$ atau Abnormal. Namun dilihat dari nilai skor koesioner SRQ terdapat 3 subjek yang masih berada pada kategori abnormal sudah mengalami penurunan skor, hal ini juga didukung dari hasil uji-t dari data pre test dan pos test sebagai mana data berikut :

Tabel 03. Uji t Pre Test- Pos Test Gangguan Psikologi

\begin{tabular}{|c|c|c|c|c|c|c|c|c|}
\hline & \multicolumn{5}{|c|}{ Paired Differences } & \multirow[b]{3}{*}{$\mathrm{t}$} & \multirow[b]{3}{*}{$\mathrm{df}$} & \multirow[b]{3}{*}{ Sig. (2-tailed) } \\
\hline & \multirow[b]{2}{*}{ Mean } & \multirow{2}{*}{$\begin{array}{c}\text { Std. } \\
\text { Deviation }\end{array}$} & \multirow{2}{*}{$\begin{array}{l}\text { Std. } \\
\text { Error } \\
\text { Mean }\end{array}$} & \multicolumn{2}{|c|}{$\begin{array}{c}\text { 95\% Confidence Interval } \\
\text { of the Difference }\end{array}$} & & & \\
\hline & & & & Lower & Upper & & & \\
\hline $\begin{array}{l}\text { Pre Test Gangguan Psikologi } \\
\text { Pos Test Gangguan Psikologi }\end{array}$ & $\begin{array}{l}8.00 \\
2.75\end{array}$ & 1.943 & .435 & 4.341 & 6.159 & 12.082 & 19 & .000 \\
\hline
\end{tabular}

Berdasarkan tabel di atas diketahui hasil uji t pada data pre test dan post test subjek penelitian menunjukkan nilai $t=6.159$ sedangkan nilai $p 0.000(p<0.05)$ hal tersebut mengartikan terdapat pengaruh yang signifikan antara data pre test dan post test pada subjek penelitian hal tersebut mengartikan terdapat pengaruh yang positif pemberian Self talk dalam mengatasi gangguan psikologi.

WHO (2015) menjelaskan bahwa kondisi psikologis atau mental yang sehat merupakan kondisi dimana seorang individu merasa sejahtera dalam hidupnya, seorang individu yang mampu mengenali potensi dirinya, mampu menghadapi tekanan dalam kehidupan sehari-hari, dan mampu memberikan kontribusi di lingkungan sosialnya. Berbagai bentuk perubahan yang terjadi saat ini akibat COVID19 berdampak pada segala aspek bagi perkembangan seperti menjalankan aktivitas secara online/daring, tidak bisa bertemu teman-temannya untuk sementara waktu, banyak pihak yang menurunnya penghasilan ekonomi dan masalah lainnya. Perubahan keadaan tersebut membuat seseorang mudah mengalami cemas bahkan yang bersifat akut sehingga sering merasa tidak tenang dalam melakukan aktivitasnya bahkan menjadikan orang tersebut terus berpikir bahwa akan ada peristiwa buruk yang mengancam keselamatannya, kehilangan rasa percaya diri, mudah lelah dan munculnya ketidak tertarikan untuk melakukan aktivitas yang biasa disukai. Untuk itu, mereka butuh suatu cara/ strategi untuk bisa menghilangkan perasaan negatif/ emosi buruknya. Salah satu cara yang bisa dilakukan adalah dengan Self Talk. Self talk adalah salah satu teknik yang memiliki tujuan untuk membantu mengubah pikiran- pikiran negatif pada diri seseorang menjadi pikiranpikiran yang bersifat positif. Self talk merupakan suatu cara untuk bisa berkomunikasi dengan diri sendiri dengan menggunakan perkataan yang terlintas 
dalam pikirannya, hal tersebut sifatnya bisa negatif maupun positif tergantung individu tersebut.

Negative Self talk dapat membuat seseorang menjadi pesimis, mudah putus ada, dan sifat lainnya yang membuatnya menjadi pribadi yang negative. Kata-kata yang termasuk Negative Self talk misalnya, “aku tidak berguna!”, “tidak ada yang bisa aku lakukan”, “aku lemah”, dsb. Sedangkan, Positive Self talk dapat membuat seseorang menjadi tenang saat menghadapi aktivitas bahkan saat berada pada masalah yang berat. Perkataan tersebut mampu meningkatkan kesehatan mental seseorang dapat dengan baik menyikapi setiap permasalahan yang dihadapinya. Bentuk pernyataannya misalnya, “aku pasti bisa!”, “aku harus semangat!”, aku orang yang kuat!", dan kata-kata lainnya yang bisa memberikan semangat pada dirinya serta mendukung kondisi mentalnya agar tetap stabil.

Teknik Self talk adalah salah satu bentuk dari terapi kognitif (Cognitive Restructuring) dimana teknik ini akan mengutamakan pernyataan positif untuk merubah pemikiran yang tidak masuk akal (irasional) seseorang baik secara verbal atau non verbal menjadi masuk akal (rasional). Teknik ini merupakan jenis dari Rational Emotive Behavior Therapy (REBT) yang dikembangkan oleh Albert Ellis. Rational Emotive Behavior Therapy (REBT) ini berfokus pada kepercayaankepercayaan irasional untuk diubah menjadi rasional agar bisa sesuai dengan fakta yang ada.

Sebelum melakukan Self Talk, sebelumnya peneliti telah mengumpulkan 20 subjek yang terindikasi mengalami gangguan psikologi melalui pre-test SRQ-20 selanjutnya melakukan teknik Self talk. Terdapat beberapa taham dalam teknik Self talk ini, yang bertujuan agar pelaksanaannya mampu berjalan dengan maksimal. Tahap pertama peneliti mendengarkan negative self talk pada diri subjek, dilaksankan dengan cara peneliti mengajak atau mengarahkan subjek untuk untuk menceritakan pengalaman tentang situasi yang menimbulkan pikiran negatifnya muncul sehingga membuat negative self talk terbentuk pada diri subjek. Kemudian, peneliti meminta subjek untuk mengidentifikasi pemikiran irasional yang menyebabkan dirinya bereaksi negative dan mengakibatkan kesehatan mentalnya bermasalah. Hasil yang didapatkan pada taham ini yaitu semua subjek dapat menceritakan dan dapat mengidentifikasi apa yang membuat pikiran negatifnya muncul.

Tahap kedua adalah menuliskan self talk, inti dari pertemuan ini adalah meminta subjek menuliskan self talk negatif ke dalam jurnal self talk miliknya. Pertama-tama peneliti membagikan jurnal Self talk kepada semua subjek penelitian, selanjutnya menjelaskan tujuan dan manfaat dari jurnal tersebut, selanjutnya meminta mereka mengumpulkan pernyataan atau kata-kata negatif yang muncul dalam menghadapi situasi yang dihadapi. Kemudian mengajaknya untuk memaparkan hasil jurnal yang telah ditulis dan meminta subjek menceritakannya.

Tahap ketiga mengubah Self talk negatif menjadi Self talk positif. Inti dari tahap ini adalah mengarahkan apa yang dipikirkan atau ucapkan subjek adalah sesuatu yang salah dan apa yang seharusnya dilakukan subjek. Sehingga subjek mengisi Self talk yang 
positif, selanjutnya peneliti membantu subjek untuk menyakinkan pada dirinya bahwa pikiran negatif dapat dilawan dan dapat diubah kedalam pikiran positif agar menimbulkan positive Self talk, serta memeberikan penguatan agar subjek memiliki keinginan untuk mengubah Self talk negatif menjadi Self talk positif dengan percaya kepada diri sendiri dan menerapkannya tanpa merasa bimbang saat diterapkan dalam aktivitas sehari-hari khususnya saat subjek menghadapi masalah.

Selanjutnya peneliti memeberikan peralihan pikiran dalam hal ini peneliti menerapkan strategi dengan mengganti perkataan negatif dengan pikiran positif yang menghasilkan Self talk positif. Selanjutnya peneliti meminta subjek untuk mempraktikannya, agar subjek memiliki kebiasaan baru berisi respon yang bersifat positif dan digunakan jika menghadapi setiap situasi dalam hidupnya. Hasil yang diperoleh adalah subjek mampu mengubah Negative Self talk menjadi Positif Self talk selanjutnya mempertahankan pemahaman tersebut secara konsisten. Kemudian peneliti meminta subjek untuk menjalankan perubahan tersebut hingga beberapa hari lalu menceritakan pengalamannya kepada peneliti perubahan apa yang dirasakan dalam hidupnya.

Tahap kelima melakukan evaluasi. Tujuan pada tahap ini untuk mengetahui perkembang kesehatan mental subjek setelah melakukan teknik self talk. Selanjutnya peneliti melakukan posttest koesioner SRQ-20 yang nanatinya akan digunakan sebagai perbandian dari sebelum melakukan teknik self talk.

Saligman \& Reichenberg (Erford, 2016) mendeskripsikan Self talk sebagai sebuah pep talk (pembicaraan yang dimaksudkan untuk membangkitkan keberanian atau antusiasme) positif yang diberikan seseorang kepada dirinya sendiri setiap hari. Teknik Self talk adalah suatu teknik yang dapat digunakan untuk menyangkal keyakinan yang tidak masuk akal dan mengembangkan pemikiran yang lebih positif, yang akan menghasilkan Self talk yang lebih positif. Self talk adalah suatu cara dari orang-orang untuk menangani pesan negatif yang mereka kirimkan kepada diri mereka sendiri.

Tujuan dari pemberian teknik Self talk adalah untuk mengubah negative Self talk menjadi positive self talk. Dengan adanya teknik Self talk maka subjek dapat menyadari pemikiran irasionalnya saat menghadapi masalah sehingga dapat menyelesaikan masalah dengan pemikiran rasional yang dipahaminya. Subjek juga mampu mengendalikan pikirannya sesuai apa yang di inginkan agar mampu mengambil keputusan secara sehat dan mandiri. Dengan melakukan pengulangan perkataan positif dalam latihan Self talk positif maka dapat menjadikan kebiasan baik yang akan menghasilkan kondisi psikologis yang sehat.

Berdasarkan data hasil post-test setelah di berikan teknik Self talk semua subjek terlihat sangat antusias dan sebagian besar mendapatkan manfaat atau perubahan dari permasalahan Kesehatan mental yang dialami. Dari 20 subjek penelitian terdapat 17 subjek mengalami perubahan yang positif setelah melakukan Self talk yang terlihat dari hasil SRQ-20 pada post-test menunjukkan tidak adanya indikasi mengalami gangguan psikologi, namun 3 subjek lainnya yang dari awal memang terindikasi mengalami gangguan psikologi yang cukup berat dari hasil post-test menunjukkan tetap menunjukkan indikasi gangguan psikologi namun dengan skor yang rendah atau 
menunjukkan perubahan yang positif meskipun masih dapak kategori indikasi mengalami gangguan psikologi. Diharapkan para subjek penelitian terus menerapkan teknik Self talk sehingga menjadikan mereka memiliki pribadi yang lebih baik dan memiliki Kesehatan mental yang baik dalam menghadai Covid-19

\section{Kesimpulan}

Hasil penelitian tentang efektivitas Self talk terhadap pengelolaan kesehatan mental di tengah pandemi covid-19 adalah sebagai berikut:

1. Tingkat kesehatan mental subjek saat pretest berada pada kategori tinggi namun saat posttest, tingkat kesehatan mental subjek mengalami perubahan ke kategori rendah.

2 Pada keseluruhan tahap pelaksanaan teknik Self talk semua subjek berpartisipasi dengan sangan antusias.

3. Penerapan teknik Self talk dapat pengelolaan kesehatan mentan subjek secara signifikan.

Berdasarkan kesimpulan hasil penelitian di atas, diajukan saran sebagai berikut:

\section{Bagi peneliti}

Peneliti dapat mempergunakan teknik Self talk sebgai layanan untuk meningkatkan kesehatan mental dalam pandemic Covid-19. Teknik Self talk dapat dikembangkan menjadi penelitian tindakan konseling dengan menetapkannya pada permasalahan yang berbeda

\section{Bagi peneliti selanjutnya}

Teknik Self talk dapat dikembangkan dengan variabel terikat lainnya secara spesifik bukan hanya pada masalah Kesehatan mental yang relatif menjadi permasalahan umum dalam psikologi dan bisa menggunakan alat ukur psikologi lain yang lebih spesifik.

\section{Referensi}

Ali, M., \& Asrori, M. (2011). Psikologi remaja - Perkembangan Pesera Didik. Cetakan ketujuh. PT. Bumi Aksara

Banerjee D. (2020). The COVID-19 outbreak: Crucial role the psychiatrists can play. Asian J. Psychiatr. https://doi.org/ 10.1016/j.ajp.2020.102014.

Brooks, S.K., Webster, R.K., Smith, L.E., Woodland, L., Wessely, S., Greenberg, N., \& Rubin, G.J. (2020). The Psychological Impact Of Quarantine And How To Reduce It: Rapid Review Of The Evidence. Lancet, 395 (10227), 912-920.

Gerungan, W.A. (1996). Psikologi Sosial. Eresco Kementerian Kesehatan RI. (2019). Pedoman. 
Idaiani, Sri; Suhardi; Antonius Yudi Kristanto. 2009. Analysis of Mental Emotional Disorder Symptoms in Indonesian People. Majalah kedokteran Indonesia. Volume: 59, Nomor: 10, Oktober 2009.

Lazarus, R. S. (1991). Emotion and adaptation. Oxford University Press.

Sadock ,J.B., \& Sadock, A.V. (2010). Kaplan \& Sadock Buku Ajar Psikiatri Klinis. Edisi ke-2. EGC

Shin, K.E. \& Newman, M.G.(2019). Self- And Other- Perceptions Of Interpersonal Problems: Effects Of Generalized Anxiety, Social Anxiety, And Depression. Anxiety Disord., 65, 1-10. https://doi.org/10.1016/j.janxdis.2019.04.005

Sugiyono. (2015) Metode Penelitian Pendidikan (Pendekatan Kuantitatif, Kualitatif, dan R\&D), Bandung: Alfabeta.

WHO. 2019. Mental Health During Covid-19 Pandemic. (diakses pada 17 Juni 2020)

Fiorillo, A., Gorwood, P., 2020. The consequences of the COVID-19 pandemic on mental health and implications for clinical practice. European Psychiatry, 63(1).

Spielberger, C. D., Gorsuch, R. L., Lushene, R., Vagg, P. R., \& Jacobs, G. A. (1983). Manual for the State-Trait Anxiety Inventory. Consulting Psychologists Press.

Sunarti, E. (2020). Paparan Hasil Survey Ketahahan Keluarga Di Masa Pandemi COVID-

19. Webinar The 14th IPB Strategic Talks COVID-19 Series: Mencegah Krisis Keluarga Indonesia di Masa Pandemi COVID-19

Wood W. \& Rünger D. (2016). Psychology of habit. Annu., 67, 289-314. https://doi.org/10.1146/annurev-psych-122414- 033417

Zandifar, A \& Badrfam, R. (2020). Iranian Mental Health During The COVID-19 Epidemic. Asian Asian $J$ Psychiatr. $51 \quad$ (101990) https://doi.org/10.1016/j.ajp.2020.101990

Zhang, J., Wu, W., Zhao, X., \& Zhang, W. (2020). Recommended Psychological Crisis Intervention Response to The 2019 Novel Coronavirus Pneumonia Outbreak In China: A Model Of West China Hospital. Precision Clinical Medicine, 3 (1),3-8, https://doi.org/10.1093/pcmedi/pbaa006 